\title{
Recent invasion and eradication of two members of the Euwallacea fornicatus species complex (Coleoptera: Curculionidae: Scolytinae) from tropical greenhouses in Europe
}

Hannes Schuler ( $\nabla$ hannes.schuler@unibz.it )

Free University of Bolzano: Libera Universita di Bolzano https://orcid.org/0000-0001-8307-9831

Radosław Witkowski

Poznan University of Life Sciences: Uniwersytet Przyrodniczy w Poznaniu

Bart van de Vossenberg

Dutch National Plant Protecion Organization

Björn Hoppe

Julius Kuhn Institute Brunswick Messeweg Campus: Julius Kuhn-Institut Standort Braunschweig-

Messeweg

Moritz Mittelbach

Senatsverwaltung für Umwelt, Verkehr und Klimaschutz

Tibor Bukovinszki

Dutch National Plant Protection Organization

Stefan Schwembacher

Autonomous Province of Bolzano: Provincia Autonoma di Bolzano

\section{Bas van de Meulengraaf}

Dutch National Plant Protection Organization

Uwe Lange

Thüringer Landesamt für Landwirtschaft

\section{Sabine Rode}

Thüringer Landesamt für Landwirtschaft

\section{Alessandro Andriolo}

Autonomous Province of Bolzano: Provincia Autonoma di Bolzano

Marta Belka

Poznan University of Life Sciences: Uniwersytet Przyrodniczy w Poznaniu

Andrzej Mazur

Poznan University of Life Sciences: Uniwersytet Przyrodniczy w Poznaniu

\section{Andrea Battisti}

University of Padova: Universita degli Studi di Padova 


\section{Research Article}

Keywords: Coleoptera, Scolytinae, Ambrosia beetle, Euwallacea fornicatus, Euwallacea perbrevis, invasive species, Polyphagous shot hole borer, Tea shot hole borer, plant health

Posted Date: July 8th, 2021

DOl: https://doi.org/10.21203/rs.3.rs-640781/v1

License: (c) (i) This work is licensed under a Creative Commons Attribution 4.0 International License.

Read Full License 


\title{
Recent invasion and eradication of two members of the Euwallacea fornicatus species complex
}

\section{(Coleoptera: Curculionidae: Scolytinae) from tropical greenhouses in Europe}

Hannes Schuler ${ }^{1,2^{*}}$, Radosław Witkowski ${ }^{3}$, Bart van de Vossenberg ${ }^{4}$, Björn Hoppe ${ }^{5}$, Moritz Mittelbach ${ }^{6}$, Tibor Bukovinszki ${ }^{4}$, Stefan Schwembacher ${ }^{7}$, Bas van de Meulengraaf ${ }^{4}$, Uwe Lange ${ }^{8}$, Sabine Rode ${ }^{8}$, Alessandro Andriolo ${ }^{9}$, Marta Bełka ${ }^{3}$, Andrzej Mazur ${ }^{3}$, Andrea Battisti ${ }^{10}$

\footnotetext{
${ }^{1}$ Faculty of Science and Technology, Free University of Bozen-Bolzano, Italy; ORCID: 0000-0001-8307-
} 9831

${ }^{2}$ Competence Centre Plant Health, Free University of Bozen-Bolzano, Italy

${ }^{3}$ Faculty of Forestry and Wood Technology, Poznań University of Life Sciences, Poland

${ }^{4}$ Dutch National Plant Protection Organization, National Reference Centre Wageningen, Netherlands

${ }^{5}$ Julius Kühn Institute (JKI) - Federal Research Centre for Cultivated Plants, Institute for National and

International Plant Health, Braunschweig, Germany; ORCID: 0000-0001-8689-4911

${ }^{6}$ Senatsverwaltung für Umwelt, Verkehr und Klimaschutz, Berlin, Germany

${ }^{7}$ Plant Protection Service of the Autonomous Province of Bozen-Bolzano, Italy

${ }^{8}$ Thüringer Landesamt für Landwirtschaft und Ländlichen Raum, Referat23 Pflanzenschutz und Saatgut, Jena, Germany

${ }^{9}$ Forest Service of Bozen-Bolzano, Italy

${ }^{10}$ DAFNAE, University of Padova, Italy; ORCID: 0000-0002-2497-3064

* Corresponding author: Hannes Schuler, hannes.schuler@unibz.it

\begin{abstract}
Ambrosia beetles of the Euwallacea fornicatus species complex are emerging tree pests with a broad host range including important agricultural crops. Native to Southeast Asia, these species were introduced into various countries, where they cause considerable damage to many tree species. Here we report several outbreaks of E. fornicatus s.l. in Europe. The first individuals were found in 2017 in a palm house of a botanical garden in Poznan (Poland) whereas in 2020 an outbreak was detected in a tropical greenhouse in Merano (Italy). In 2021, two additional outbreaks were detected in two greenhouses in Germany, in Erfurt and Berlin. For the latter cases it was possible to trace back the invasion to a distributor of exotic plants in the Netherlands where several infected plants were detected. Molecular analysis show that individuals from Poland and Italy are genetically identical but belong to a different mitochondrial clade than individuals in Germany which are identical to most individuals of two greenhouses in the Netherlands. Moreover, in the two greenhouses in the Netherlands we found beetles that belong to another haplotype of E. fornicatus and two haplotypes of E. perbrevis, a species in the E. fornicatus complex, which has not been previously
\end{abstract}


intercepted in Europe. Our study provides novel insights into the invasion history of $E$. fornicatus and the first eradication measures in Europe. Considering the high potential of introduction and establishment of Euwallacea ambrosia beetles, particular attention should be paid to monitor the presence of these pests in greenhouses across Europe.

\section{Keywords}

Coleoptera, Scolytinae, Ambrosia beetle, Euwallacea fornicatus, Euwallacea perbrevis, invasive species, Polyphagous shot hole borer, Tea shot hole borer, plant health

\section{Key message}

- The polyphagous shot-hole borer (PSHB) Euwallacea fornicatus is a serious polyphagous invasive pest species

- The first known records of this quarantine pest in tropical greenhouses in Europe are presented

- The beetles were likely introduced with infested plants as confirmed by the detection of E. fornicatus at a plant supplier in the Netherlands

- Mitochondrial DNA sequencing revealed at least two independent introduction events

- The tea shot hole borer (TSHB) Euwallacea perbrevis, which was not detected elsewhere in EU, was also found at the same supplier in the Netherlands

- This study provides novel insights in the invasion and the ongoing eradication of an emerging invasive pest species in Europe

\section{Declarations}

Funding: Internal funds of the Free University of Bozen-Bolzano to H.S., Forest Service of Bozen-Bolzano, Italy and European Union's Horizon 2020 Program for Research and Innovation 'HOMED' [grant no. $771271]$ to A.B.

Conflicts of interest: The authors declare that they have no conflicts of interest.

Ethics approval: This article does not contain any studies with human participants or animals (vertebrates) performed by any of the authors.

Consent to participate: Not applicable 
Consent for publication: Not applicable

Availability of data and material: Sequence data will be deposited into the Genbank. The datasets generated and/or analyzed during the current study are available from the corresponding author on reasonable request.

Code availability: No custom code was used.

Author's contribution statement: AB, HS conceived and designed research. AA, AM, BvdV, BH, BvdM, HS, MB, MM, SS, SR, RW, UL, TB, conducted experiments. HS, BvdV performed data analysis. HS and AB wrote the manuscript with contribution of all authors.

Acknowledgments: The authors would like to thank the administration of the Poznań Palm House for sharing materials and giving full access to the site. Erika Corretto, Patrizia Elena Vannucchi and Wietse den Hartog for technical assistance. Zvi Mendel and Stanley Freeman for helpful comments and suggestions.

\section{Introduction}

Members of the Euwallacea fornicatus species complex (Coleoptera: Curculionidae: Scolytinae) are severe agricultural pests in most parts of the world (Beaver 1976; Li et al. 2016; Ge et al. 2017). They are one of a few examples of ambrosia beetles that are able to infest healthy plants (Gomez et al. 2019). The E. fornicatus species complex has a broad host range of 412 plant species in 75 families (Gomez et al. 2019) including important agricultural crops such as tea (Camellia sinensis), mango (Mangifera indica) and avocado (Persea americana) (Eskalen et al. 2013; Carrillo et al. 2016); Danthanarayana 1968; Yamaguchi et al. 2006). They are associated with at least three symbiotic fungi Fusarium euwallaceae, Graphium euwallaceae and Paracremonium pembeum (syn. Acremonium pembeum) (Carrillo et al. 2016; Freeman et al. 2016; Lynch et al. 2016). Some of these vectored fungi are plant pathogens causing avocado dieback in California (USA) and Israel (Eskalen et al. 2012, 2013; Freeman et al. 2013).

Euwallacea fornicatus s.l. is native to Southeast Asia with confirmed records in China, Japan, Malaysia, the Philippines, Taiwan, Sri Lanka, Thailand, and Vietnam (CABI 2021, Stouthamer et al. 2017). Outside its native range, E. fornicatus s.l. invaded various countries in North and Central America (USA, Panama, Costa Rica), Africa (South Africa, Réunion), Oceania (Australia, Papua New Guinea, Fiji and other countries), and Israel (Kirkendall and Ødegaard 2007; Cooperband et al. 2016, CABI 2021). In Europe, E. fornicatus s.l. is considered a quarantine pest and is included in the Annex II Part A within the group "Scolytidae spp. (nonEuropean)" (Commission Implementing Regulation EU 2019/2072). Its explicit listing in Annex II is anticipated by the end of 2021. Its wide host range makes E. fornicatus s.l. a serious threat for agriculture but also forestry, ornamental plants, and botanical gardens. 
113 Several outbreaks were recently discovered in tropical greenhouses of botanical gardens in Europe. In 2017,

114 specimens of E. fornicatus were found on a sacred fig (Ficus religiosa) tree in a palm house in Poznań,

115 Poland (EPPO 2019), whereas various tropical plants have been attacked by E. fornicatus in a greenhouse in

116 Merano, Italy (EPPO 2020). Recently, two other cases have been reported in Germany in two tropical

117 greenhouses in Thuringia (EPPO 2021a) and Berlin (EPPO 2021b) and in a greenhouse in the Netherlands

118 (EPPO 2021c). Although tracing information of consignments has been used to establish the origin of

119 infested plants, analysis of molecular data may provide direct insights into the invasion history of

120 Euwallacea and thus into the dynamics of introduction events across the different locations. Here we

121 perform a comparative genetic analysis of insects from different locations in Europe and attempt to trace

122 back the introduction pathway of the beetles. Moreover, we report the subsequent eradication measures. Our

123 study provides new insights into the introduction and the subsequent steps to eradicate these invasive insect

124 pest species.

\section{Materials and methods}

\section{Detection and identification}

130 A sacred fig tree (Ficus religiosa) in the Poznań Palm House (Poland) showed branch dieback and visible frass, typical symptoms for infestation with ambrosia beetles in March 2017. An approximately $1 \mathrm{~m}$ long branch of the tree was cut and placed in a breeding container. Emerging beetles were collected for taxonomic identification. In April 2020, several trees in the tropical greenhouse of the Gardens of Trauttmansdorff Castle in Merano (Italy), showed boreholes and ejection of wooden debris. Emerging insects were directly collected from infested plants, from the walls of the greenhouse and dissected from trap logs deployed in the greenhouse. In addition, two plants, one Mangifera indica and one Tectona grandis, showed symptoms of a bark beetle infection in a tropical greenhouse in Erfurt (Germany) in January 2021 and two months later several plants in a greenhouse in Berlin (Germany) showed resin flows on stems and boreholes with small protruding tubes of compacted sawdust. Emerging beetles were collected and stored in ethanol. In the Netherlands, several plants were found to be infested at two plant nurseries (NL1 and NL2) and where beetles were extracted.

Identification of the insect material was carried out using taxonomic keys available in the literature (Smith et al. 2020; Wood and Bright 1992; Rabaglia et al. 2006; Wood 2007; Smith et al. 2019) by the Poznań University of Life Sciences in Poland, by the Laboratory for Virology and Diagnostics of the Research

146 Centre Laimburg in Italy and by the federal plant protection agencies in Thuringia and Berlin and the

147 National reference laboratory of the Julius-Kühn Institute (JKI) in Braunschweig in Germany and by the National Reference Centre of the NPPO in the Netherlands. 
DNA extraction and sequencing

151

152

153

154

155

156

157

158

159

160

161

162

163

164

165

166

167

168

169

170

171

172

173

174

175

176

177

178

179

180

181

182

183

184

185

A total of 32 individuals were analyzed including three individuals from Poland, 9 individuals from Italy, three individuals from Erfurt and 17 from Berlin. Individuals were genotyped using the primers Lep-R1 (Hebert et al. 2004). Moreover, in the Netherlands, in a total of 32 beetle specimens from the Dutch outbreak locations (18 beetle specimens from NL1 and 14 beetle specimens from NL2) were included in the analysis. Details about the extraction protocol, PCR conditions and sequencing can be found in supplementary document S1.

\section{Cluster analysis}

Relationship of the obtained sequences was determined using 83 partial mitochondrial COI sequences obtained from NCBI GenBank and the 64 partial COI sequences generated in this study. Sequences were aligned using the MAFFT aligner (Katoh et al. 2002; Katoh and Standley 2013) incorporated in Geneious Prime v2021.1.1 (BioMatters, New Zealand). Terminal positions in the alignment that were not covered by all sequences in the dataset were masked resulting in a 564 bp alignment used for clustering analysis. A maximum likelihood tree was constructed with FastTree (Price et al. 2010) using the generalized timereversible (GTR) model and 1,000 bootstraps to determine confidence levels of internal nodes. The cox 1 sequence of Euwallacea andamanensis isolate PR13-238 (KU727039) was used to root the E. fornicatus s.l. sequences.

\section{Eradication and surveillance}

In Poland, immediately after the outbreak was noticed, actions limiting its spread were undertaken. The whole sacred fig tree was covered with Storanet ${ }^{\circledR}$ BASF Agrar (insect-proof net impregnated with alphacypermethrin) and the tree was subsequently removed and burnt under controlled conditions. The soil around the roots was excavated and the surrounding area was treated with the fungicide Topsin M (ThiophanateMethyl, 100 ppm concentration). Beetle surveillance with 4 triangle barrier traps IBL-2 (baited with 98\% ethanol) started immediately and continued for a year after removal of the infested tree. Furthermore, plant health conditions in the palm house were monitored by visual observation of symptoms.

After the first detection of E. fornicatus in Italy, an intense monitoring has started inside the greenhouse and in the surrounding area. Due to the advanced outbreak, all the plants in the greenhouse, including their roots, were removed and destroyed under official control in June 2021. The greenhouse was also subjected to solarization for a period of three months. Simultaneously, three sticky traps baited with quercivorol and alpha-copaene according to (Kendra et al. 2019) and several trap logs of Acer negundo (diameter 4-10 cm, length 30-60 cm) were placed inside the greenhouse to verify the possible presence of adults. In the area external to the greenhouse, two traps were deployed at 500 and $1000 \mathrm{~m}$ from the tropical greenhouse in each cardinal direction, for a total of eight traps. All traps were weekly checked. Visual inspections from the 
ground, ladders and hoisting platforms were implemented in- and outside of the infested greenhouse. Known host plants of the beetle (Acer spp., Citrus spp., Platanus spp., etc.) were monitored for boreholes especially after favorable weather conditions. Additionally, weakening tree parts or branches were inspected for symptoms.

After the introduction in Germany, monitoring inside and outside the respective greenhouse have been initiated, using the setup described above, consisting of trap logs containing quercivorol pheromones. In the plant nurseries of Netherlands, ethanol and acetic acid-baited traps were placed in all greenhouse compartments for one week (18 traps at NL1, 6 traps at NL2). Later sticky traps baited with quercivorol and alpha-copaene were placed in the greenhouse compartments at eight positions in both greenhouses.

\section{Results}

\section{Detection and eradication}

In Poland, the sacred fig sample yielded over 1,000 specimens of E. fornicatus. No beetles were caught by the traps for one year after the first detection. Plants, occurring in the same pavilion as the infested sacred fig and plants in neighboring pavilions, which were subjected to regular inspections did not show symptoms of ambrosia beetles and fungal infection.

In Italy, a total of 28 trees of 21 different species (Annona muricata, Artocarpus heterophyllus, Averrhoa carambola, Bixa orellana, Bulnesia arborea, Cananga odorata, Clausena lansium, Crescentia cujete, Debregeasia edulis, Dimocarpus longan, Ficus altissima, Ficus sp., Justicia sp., Kigelia africana, Melicoccus bijugatus, Mangolia champaca, Millettia brandisiana, Persea americana, Terminalia catappa, Terminalia buceras, Theobroma cacao) showed boreholes and ejection of wooden debris. Intensity of infestation, diameter of infested trees and distribution of the boreholes on the plant differ strongly between species and individual plants. Annona muricata and Bixa orellana were the most heavily infested plants, showing more than five holes per $\mathrm{dm}^{2}$. The highest density of boreholes was observed next to fresh and older cut branches and on thinner parts in the crown/upper stem. The presence of boreholes was also observed in twigs less than $2 \mathrm{~cm}$ of diameter of Dimocarpus longan and Justicia spp. trees. No beetles were caught in the traps deployed outside of the tropical greenhouse and visual inspection of susceptible host trees did not result in finding of symptoms of beetle attack.

The two recent findings in Germany revealed that in Erfurt just two plants, one Mangifera indica and one Tectona grandis, were attacked by E. fornicatus, whereas in Berlin 136 shrubs and trees of Clusia rosea, Heteropanax sp., Ficus sp., and Mangifera indica showed symptoms. All infested plants were destroyed and surveillance started in both localities. 
In the Netherlands, at both locations all infested plants were destroyed. The sale and transport of all woody plants and palms (Arecaceae) in the two greenhouses in the Netherlands was put on hold followed by intensive visual inspection of all consignments by the phytosanitary authorities.

\section{Reconstruction of the invasion}

Trace-back investigations revealed that the $F$. religiosa tree infected with E. fornicatus in Poland was imported in November 2016 from the Netherlands. The infection has already been detected five months later and subsequent phytosanitary measures impeded the dispersion to other trees. The advanced outbreak in Italy with 21 different species attacked at the time of detection, hindered a detailed reconstruction of the invasion. The greenhouse in Italy was established in 2014 and most plants were purchased between 2013 and 2014. No symptoms of beetle attack were reported in the first years following the establishment. Additionally, one $T$. cacao plant was replaced in 2018, which was the same that two years later was discovered to be attacked by E. fornicatus. Both infested plants in Erfurt, and most of the infested plants in Berlin were acquired and imported from a distributor of exotic plants in the Netherlands in 2020.

Following a trace-back of the notification in the Erfurt case, we were able to link these infestations to a Dutch greenhouse for commercial sale of tropical plants (NL1). A follow up survey resulted in several trees that were attacked by ambrosia beetles. Samples were collected from a Ficus microcarpa individual that contained specimens of the Euwallacea fornicatus s.l. in March 2021. Additionally, beetles were collected from Bauhinia x blakeana, Ficus microcarpa 'Panda', Ficus sp., Ficus maclellandii 'Alii' and Ficus 'Amstel King' whereas one individual was collected from a trap. A following survey in another greenhouse associated with the company (NL2) resulted in the discovery of several additional symptomatic trees. At location NL2, individuals were collected from $F$. benjamina 'Exotica', F. foliole and Ficus lyrata. A total of 32 individuals from the two populations in the Netherlands (18 from NL1, 14 from NL2) were subsequently genotyped and included in our cluster analysis.

\section{Molecular identification}

All individuals from Poland and Italy were genetically identical (Genbank acc. Number TBA) but different from the individuals found in Germany and the Netherlands. The haplotype described in Poland and Italy clustered with a haplotype of the PSHB clade which according to Smith et al. (2019) is E. fornicatus. However, none of the haplotypes described in E. fornicatus populations in their native and invasive range were identical to the haplotype described in these two localities. The cluster analysis showed that the prevalent COI haplotype in Europe was most related to a haplotype present in Vietnam (Stouthamer et al. 2017; Fig. 1). In contrast all individuals from Germany and the Netherlands share the same haplotype (Genbank acc. Number TBA) which is related to a population previously genotyped in Taiwan (Stouthamer et al. 2017). Moreover, two individuals from the Netherlands (NL2) belonged to a PSHB haplotype that did not match any of the haplotypes uncovered at the other locations.(Stouthamer et al. 2017) 
261 Sequence analysis of 32 individuals from the Netherlands revealed four haplotypes. Thirteen individuals of

262 location NL1 clustered with E. fornicatus in the PSHB clade 3A (Stouthamer et al. 2017) whereas five

263 individuals belonged to two haplotypes of the TSHBa clade (Genbank acc. Number TBA) which according

264 to Smith et al. (2019) is now considered Euwallacea perbrevis. All sequenced individuals from NL2

265 belonged to two mitochondrial haplotypes that clustered with E. fornicatus in the PSHB clade 3A (Fig. 1).

266 The CO1 sequences of 25 of the PSHB clade $3 \mathrm{~A}$ individuals from both locations in the Netherlands were

267 identical to those from the Erfurt and Berlin interceptions, but not to those from Italy and Poland

268 interceptions (Fig. 1).

\section{Discussion}

Botanical gardens and greenhouses are hotspots for invasive species (Wang et al. 2015). The deliberate import of alien plants might lead to the invasion of non-native plants (Hulme 2011) but might also lead to the introduction of associated insects (Scott-Brown et al. 2018). Although introduced insects might suffer from the climatic conditions in the new environment, greenhouses play an important role in helping them to adapt to the new environment, eventually aiding the establishment and invasion of non-native insect species (Wang et al. 2015). Here we show an additional example of a recent introduction of two non-native insect pests in botanical gardens of Europe.

Ambrosia beetles of the Euwallacea fornicatus species complex are invasive species introduced into various continents but had not been detected in Europe. Here we describe the recent outbreaks of E. fornicatus in four tropical greenhouses in Poland, Italy, and Germany. We reconstructed the invasion history and its invasion route. Molecular characterization of 12 individuals from Poland and Italy showed that all individuals share the same mitochondrial haplotype, suggesting that they were likely introduced from the same source population. The haplotype belongs to the Polyphagous shot hole borer clade (Stouthamer et al. 2017) and most related to a haplotype found in Vietnam (Stouthamer et al. 2017; Fig. 1). Since the haplotype was not described elsewhere, we could not determine the exact source population. In contrast, the populations in Germany and the Netherlands were related to a different haplotype which has been previously described in Taiwan (Stouthamer et al. 2017). This highlights that the cases from Germany likely resulted from an introduction via one of the greenhouses of the commercial nursery in the Netherlands whereas the cases from Poland and Italy resulted from an independent introduction event, likely from the same source population. The additional detection of $E$. perbrevis in a greenhouse in the Netherlands highlights a third introduction event of a species which has not been found elsewhere in Europe. was present in a single sacred fig tree (Ficus religiosa) and not found in any other tree species in the same 
greenhouse, in Italy beetles have been detected already in 28 different plants belonging to 21 species. It seems likely that the E. fornicatus was introduced to Poland with an infested F. religiosa tree in 2016 and eradicated a few months later in the initial phase of its establishment. In contrast, the outbreak in Italy was more advanced when it was discovered in 2020. The most plausible explanation is that the ambrosia beetle was introduced with the $T$. cacao plant purchased in 2018 and subsequently attacked other plant species in the greenhouse where the outbreak was detected two years later. In Erfurt both infected trees of Mangifera indica and Tectona grandis, as well as most of the 136 infected trees in Berlin were imported from the Netherlands. In both cases, the presence of the beetle was detected a few months after their introduction.

Greenhouses might act as a springboard for non-native species if they are able to adapt and disperse to novel environments (Wang et al. 2015). Although E. fornicatus might not be able to survive the outdoor conditions prevailing in Poland, Germany and the Netherlands, Mediterranean conditions in Italy might allow an establishment of the beetles in this area. Moreover, all affected greenhouses are surrounded by several native and non-native trees and shrubs, known as potential hosts for E. fornicatus. The occurrence of $E$. fornicatus in the greenhouse of a retailer in the Netherlands and especially the description of E. perbrevis, which has not been described elsewhere in Europe highlights the need of more efficient examinations of imported exotic plants prior to re-sale. While eradication may be relatively simple in a greenhouse environment, it becomes much more problematic once a population is established outdoors.

315 Therefore, we argue that surveillance should be also intensified in tropical greenhouses in order to reduce the likelihood of an establishment in nature. 
318 Phylogenetic tree based on partial (564 bp) mitochondrial coxl gene sequences representing the relation of

319 the individuals found in Europe (in bold and italics) with haplotypes described in other studies.

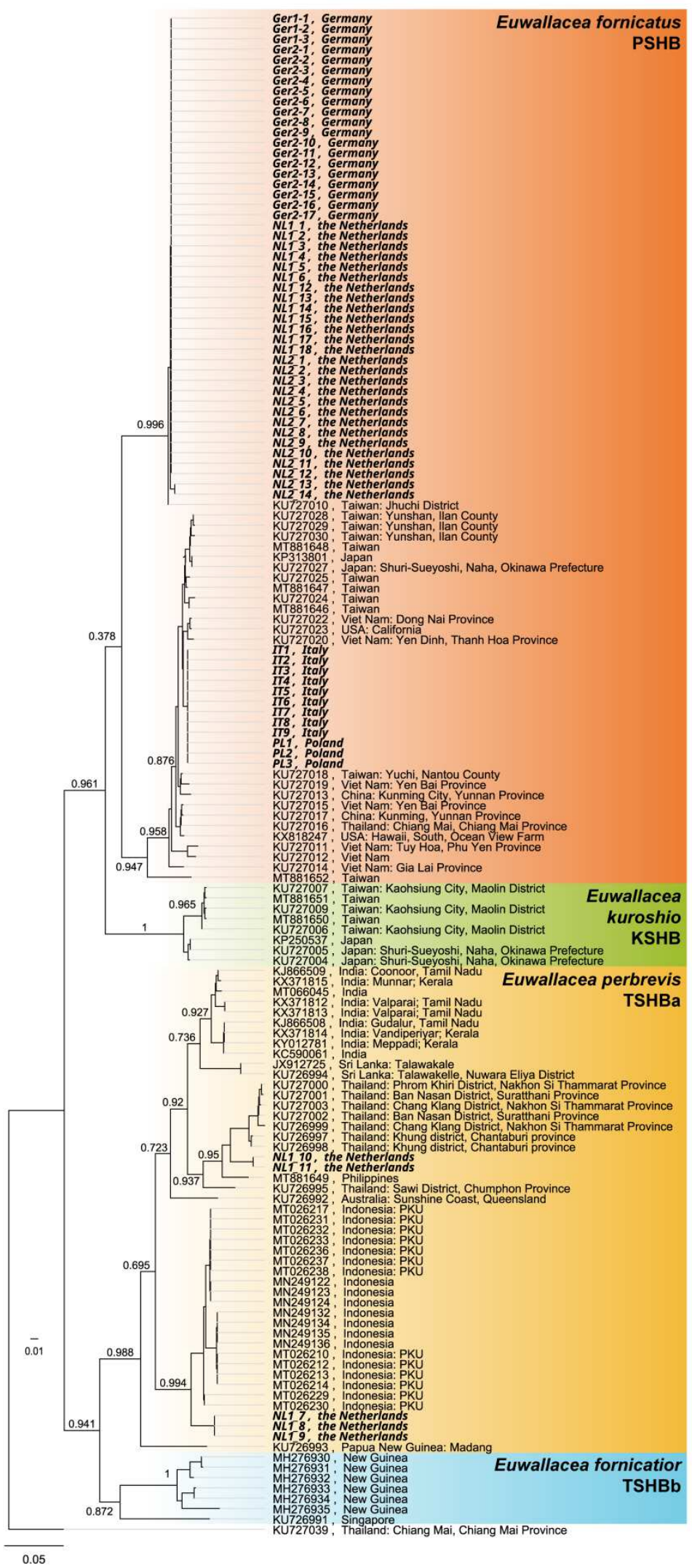




\section{References}

Beaver RA (1976) The biology of Samoan bark and ambrosia beetles (Coleoptera, Scolytidae and Platypodidae). B Entomol Res 65:531-548. https://doi.org/10.1017/s0007485300006210

CABI (2021) Euwallacea fornicatus distribution map https://www.cabi.org/isc/datasheet/18360453 [accessed on 15 April 2021].

Carrillo D, Cruz LF, Kendra PE, et al (2016) Distribution, pest status and fungal associates of Euwallacea nr. fornicatus in Florida Avocado Groves. Insects 7:55. https://doi.org/10.3390/insects7040055

Cooperband MF, Stouthamer R, Carrillo D, et al (2016) Biology of two members of the Euwallacea fornicatus species complex (Coleoptera: Curculionidae: Scolytinae), recently invasive in the U.S.A., reared on an ambrosia beetle artificial diet. Agric For Entomol 18:223-237. https://doi.org/10.1111/afe.12155

Danthanarayana W (1968) The distribution and host-range of the shot-hole borer (Xyleborus fornicatus Eichh.) of tea. Tea Q. 39: 61-69.

EPPO (2019) First finding of Euwallacea fornicatus in Poland, EPPO Reporting Service no. 02 - 2019

EPPO (2020) First report of Euwallacea fornicatus in Italy, EPPO Reporting Service no. 05 - 2020

EPPO (2021a) First report of Euwallacea fornicatus in Germany, EPPO Reporting Service no. 02 - 2021

EPPO (2021b) New finding of Euwallacea fornicatus in Germany, EPPO Reporting Service no. 03 - 2021

EPPO (2021c) First report of Euwallacea fornicatus sensu lato and cf. Cryphalus sp. in the Netherlands, EPPO Reporting Service no. 04 - 2021

Eskalen A, Gonzalez A, Wang DH, et al (2012) First Report of a Fusarium sp. and its vector Tea shot hole borer (Euwallacea fornicatus) causing fusarium dieback on avocado in California. Plant Dis 96:10701070. https://doi.org/10.1094/pdis-03-12-0276-pdn

Eskalen A, Stouthamer R, Lynch SC, et al (2013) Host range of fusarium dieback and its ambrosia beetle (Coleoptera: Scolytinae) vector in Southern California. Plant Dis 97:938-951. https://doi.org/10.1094/pdis-11-12-1026-re

Freeman S, Sharon M, Dori-Bachash M, et al (2016) Symbiotic association of three fungal species throughout the life cycle of the ambrosia beetle Euwallacea nr. fornicatus. Symbiosis 68:115-128. https://doi.org/10.1007/s13199-015-0356-9

Freeman S, Sharon M, Maymon M, et al (2013) Fusarium euwallaceae sp. nov.-a symbiotic fungus of Euwallacea sp., an invasive ambrosia beetle in Israel and California. Mycologia 105:1595-1606. https://doi.org/10.3852/13-066

Ge X, Jiang C, Chen L, et al (2017) Predicting the potential distribution in China of Euwallacea fornicatus (Eichhoff) under current and future climate conditions. Sci Rep 7:906. https://doi.org/10.1038/s41598017-01014-w 
Gomez DF, Lin W, Gao L, Li Y (2019) New host plant records for the Euwallacea fornicatus (Eichhoff) species complex (Coleoptera: Curculionidae: Scolytinae) across its natural and introduced distribution. Journal of Asia-Pacific Entomology 22:338-340. https://doi.org/10.1016/j.aspen.2019.01.013

Hebert PDN, Penton EH, Burns JM, et al (2004) Ten species in one: DNA barcoding reveals cryptic species in the neotropical skipper butterfly Astraptes fulgerator. P Natl Acad Sci Usa 101:14812-14817. https://doi.org/10.1073/pnas.0406166101

Hulme PE (2011) Addressing the threat to biodiversity from botanic gardens. Trends Ecol Evol 26:168-174. https://doi.org/10.1016/j.tree.2011.01.005

Katoh K, Misawa K, Kuma K, Miyata T (2002) MAFFT: a novel method for rapid multiple sequence alignment based on fast Fourier transform. Nucleic Acids Res 30:3059-3066. https://doi.org/10.1093/nar/gkf436

Katoh K, Standley DM (2013) MAFFT Multiple Sequence Alignment Software Version 7: Improvements in performance and usability. Mol Biol Evol 30:772-780. https://doi.org/10.1093/molbev/mst010

Kendra PE, Montgomery WS, Narvaez TI, Carrillo D (2019) Comparison of trap designs for detection of Euwallacea nr. fornicatus and other Scolytinae (Coleoptera: Curculionidae) that vector fungal pathogens of avocado trees in Florida. J Econ Entomol 113:980-987. https://doi.org/10.1093/jee/toz311

Kirkendall LR, Ødegaard F (2007) Ongoing invasions of old-growth tropical forests: establishment of three incestuous beetle species in southern Central America (Curculionidae: Scolytinae). Zootaxa 1588:53-62. https://doi.org/10.11646/zootaxa.1588.1.3

Li Y, Gu X, Kasson MT, et al (2016) Distribution, host records, and symbiotic fungi of Euwallacea fornicatus (Coleoptera: Curculionidae: Scolytinae) in China. Fla Entomol 99:801-804. https://doi.org/10.1653/024.099.0441

Lynch SC, Twizeyimana M, Mayorquin JS, et al (2016) Identification, pathogenicity and abundance of Paracremonium pembeum sp. nov. and Graphium euwallaceae sp. nov.- two newly discovered mycangial associates of the polyphagous shot hole borer (Euwallacea sp.) in California. Mycologia 108:313-329. https://doi.org/10.3852/15-063

Price MN, Dehal PS, Arkin AP (2010) FastTree 2 - Approximately maximum-likelihood trees for large alignments. Plos One 5:e9490. https://doi.org/10.1371/journal.pone.0009490

Rabaglia RJ, Dole SA, Cognato AI (2006) Review of American Xyleborina (Coleoptera: Curculionidae: Scolytinae) occurring North of Mexico, with an illustrated key. Ann Entomol Soc Am 99:1034-1056. https://doi.org/10.1603/0013-8746(2006)99

Scott-Brown AS, Hodgetts J, Hall J, et al (2018) Potential role of botanic garden collections in predicting hosts at risk globally from invasive pests: a case study using Scirtothrips dorsalis. J Pest Sci 91:601-611. https://doi.org/10.1007/s10340-017-0916-2

Smith SM, Gomez DF, Beaver RA, et al (2019) Reassessment of the species in the Euwallacea fornicatus (Coleoptera: Curculionidae: Scolytinae) complex after the rediscovery of the "lost" type specimen. Insects 10:261. https://doi.org/10.3390/insects10090261

Stouthamer R, Rugman-Jones P, Thu PQ, et al (2017) Tracing the origin of a cryptic invader: phylogeography of the Euwallacea fornicatus (Coleoptera: Curculionidae: Scolytinae) species complex. Agric For Entomol 19:366-375. https://doi.org/10.1111/afe.12215 
Wang C, Zhang X, Pan X, et al (2015) Greenhouses: hotspots in the invasive network for alien species. Biodivers Conserv 24:1825-1829. https://doi.org/10.1007/s10531-015-0876-X

Wood SL, Bright DE (1992) A catalog of Scolytidae and Platypodidae (Coleoptera), Part 2: Taxonomic index volume A. Great basin naturalist memoirs, No 13, A catalog of Scolytidae and Platypodidae (Coleoptera), Part 2: Taxonomic Index Volume A

Wood S. L. 2007., Bark and ambrosia beetles of South America (Coleoptera: Scolytidae) (Monte L. Bean Life Science Museum, Brigham Young University, Provo, 2007), 900 p.

Yamaguchi T, Iwamoto J, Goto H, Nojima H, Omatu N, Torigoe H, Yasuda K, Setokuchi O, Hayashikawa S (2006) Insect pests of the mango plant, Mangifera indica, on the Amami islands, Japan. Kyushu Plant Protection Research 52: 60-65. 


\section{Supplementary Files}

This is a list of supplementary files associated with this preprint. Click to download.

- Suppldocument1.pdf 